\title{
Research on the relation between financial performance and social
}

\section{responsibility performance in financial and insurance industry}

\author{
Xinling $\mathrm{Du}^{1, \mathrm{a}}$ and Fen Chen ${ }^{1, \mathrm{~b}^{*}}$ \\ 1Beijing Normal University Zhuhai Campus, Zhuhai 519087, China \\ ${ }^{*}$ Corresponding Author, Chen Fen

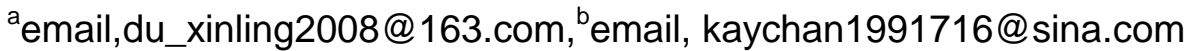

Keywords: Financial performance; Enterprise social responsibility; Social responsibility performance; Financial and insurance industry

\begin{abstract}
Financial industry and insurance industry are both the leading business in our economy and optimal benchmark business for social responsibility performance evaluation. Therefore, the paper took 27 listed companies in financial and insurance industry in Shanghai and Shenzhen A-share market as the objects of study, and made an empirical analysis on the correlation of financial performance and social responsibility performance in this industry by using the method of regression analysis. The results proved that good financial performance can guarantee the good social responsibility performance which contributes to the improvement of financial performance.
\end{abstract}

\section{Introduction}

As part of the national economy, financial and insurance industries have better fulfilled the social responsibility in the pursuit of financial performance. Due to the high value of enterprise social responsibility performance from all aspects in the society, enterprises are forced to better fulfilled social responsibilities; listed companies in financial and insurance industry chose third-party authorities to audit the social responsibility report in order to guarantee the quality. In that way, the key in the study is to find whether the good financial performance can promote the better fulfillment of social responsibilities or the good social responsibility performance can bring good financial performance. There are 40 listed companies in financial and insurance industry in Shanghai and Shenzhen stock market, and the data missing companies were eliminated from the 40 listed companies. The paper took 27 companies of the 40 listed ones as the research objects; the data of the related financial performance indexes in financial and insurance industry annual report are collected from Oriental Wealth website, and the data of financial and insurance industry social responsibility evaluation are from the blue book released by Rankins CSR Ratings. Taking 2011 as the base year, the paper made empirical analysis on correlation between enterprise financial performance and social responsibility performance according to the data from 2010 to 2012.

\section{Theoretical analysis and research hypothesis}

Theoretical analysis. Carroll (2001), an American economist, first comprehensively put forward the concept of social responsibility performance which contains social moral, economic and legal 
comprehensive social responsibility performance. It's widely believed in academic circles that stakeholders involved with social responsibility performance contain shareholders of the enterprise, customers, employees and government. As research continues, the research on correlation between social responsibility and financial performance can be conducted from the aspect of stakeholders and cost-benefit.

Research hypothesis. Assumption 1: the current enterprise financial performance and current social responsibility performance are in positive correlation. Assumption 2: the current enterprise financial performance and later social responsibility performance are in positive correlation. Assumption 3: the early enterprise social responsibility performance and current financial performance are in positive correlation.

\section{Design of related indexes}

The design of financial performance indexes. The index of financial performance is measured by return on equity. Higher return on equity indicates higher earnings from company investment.

The design of social responsibility performance. Social responsibility performance does not only contain enterprises, customers, employees and government, but also the evaluation on society and surrounding from enterprise. The paper measured social performance index by scores on listed companies of financial and insurance industry in A-share market in the blue book of social responsibility report released by Rankins CSR Ratings. Rankins CSR Ratings is the authoritative third-party rating agency for social responsibility of Chinese enterprises; the CSR Ratings include ESG rating (environment, social responsibility, government), CSR report rating, investor service for social responsibility, etc.

\section{Model building}

$$
\begin{aligned}
& \mathrm{CSP}_{t}=\alpha \mathrm{CFP}_{t}+\beta \\
& \mathrm{CSP}_{t}=\alpha^{\prime} \mathrm{CFP}_{t-1}+\beta^{\prime}
\end{aligned}
$$

Of which, $\alpha$ and $\alpha^{\prime}$ stand for regression coefficient, CSP stands for social responsibility performance index, $\mathrm{t}$ stands for the number of current period, $\mathrm{t}-1$ stands for the number of later period, CFP stands for financial performance index, $\beta$ and $\beta^{\prime}$ are intercept.

\section{Empirical analysis}

Correlation between current enterprise financial performance and current social responsibility performance. Correlation analysis: The paper chose the year of 2011 as the base year, analyzed the correlation between financial performance data in 2011 and social responsibility performance data in 2011, and received the result which was 0.802 . CFP and social responsibility performance are positively related, and the value of sig is 0.000 ; when the confidence is above $99 \%$, irrelevant 
assumptions are rejected, which means enterprise current CFP and current social responsibility performance are positively related with good correlation.

Regression analysis. According to the results of regression analysis in Table 1, Table 2 and Table 3 , it can be seen that the coefficient $\mathrm{R}$ is 0.802 , the degree of fitting is good and the parts of explained variables that can be explained by model are more and vice versa. Moreover, the statistical observation $\mathrm{F}$ is 44.922 , and sig value is 0.000 that is less than significance level 0.01 , so the overall linear relation between explained variables and explanatory variable is obvious; the linear model can be established.

According to the coefficient analysis on multiple regressions, the off-standard coefficient of CFP is 2.242 , and the corresponding sig value is 0.000 when the Significance level is 0.01 , which means the CFP and social responsibility performance is positively related. It is indicated that the financial performance and social responsibility performance in financial and insurance industry are positively related.

Table 1 Model Summary ${ }^{\mathrm{b}}$

\begin{tabular}{|c|c|c|c|c|}
\hline Model & R & R Square & $\begin{array}{c}\text { Adjusted R } \\
\text { Square }\end{array}$ & $\begin{array}{c}\text { Std. Error of } \\
\text { the Estimate }\end{array}$ \\
\hline 1 & $0.802^{\mathrm{a}}$ & 0.642 & 0.628 & 10.91818 \\
\hline
\end{tabular}

a. Predictive variable (constant), financial performance.

b. Dependent variable: social responsibility performance.

Table 2 Anova $^{\mathrm{b}}$

\begin{tabular}{|l|c|c|c|c|c|}
\hline \multicolumn{1}{|c|}{ Model } & Sum of square & df & $\begin{array}{c}\text { Mean } \\
\text { Square }\end{array}$ & F & sig \\
\hline 1 & 5354.985 & 1 & 5354.985 & 44.922 & $0.000^{\mathrm{a}}$ \\
\cline { 2 - 6 } $\begin{array}{c}\text { Regression } \\
\text { Residual } \\
\text { Total }\end{array}$ & 2980.169 & 25 & 119.207 & & \\
\cline { 2 - 6 } & 8335.154 & 26 & & & \\
\hline
\end{tabular}

a. Predictive variable(constant), financial performance.

b. Dependent variable: social responsibility performance.

Table 3 Coefficients ${ }^{\mathrm{a}}$

\begin{tabular}{|c|c|c|c|c|c|}
\hline Model & \multicolumn{2}{|c|}{$\begin{array}{c}\text { Unstandardized } \\
\text { Coefficients }\end{array}$} & $\begin{array}{l}\text { Standardized } \\
\text { Coefficients }\end{array}$ & \multirow[t]{2}{*}{$\mathrm{T}$} & \multirow[t]{2}{*}{ sig } \\
\hline 1 & $\mathrm{~B}$ & Std. Error & Beta & & \\
\hline (constan & 25.137 & 5.011 & & 5.016 & 0.000 \\
\hline CFP & 2.242 & 0.335 & 0.802 & 6.702 & 0.000 \\
\hline
\end{tabular}

a. Dependent variable: social responsibility performance.

Correlation between current enterprise financial performance and later period social responsibility performance. Correlation analysis: The paper chose the year of 2011 as the base year; analyzed the correlation between financial performance data in 2011 and social responsibility performance data in 2012, and received the result which was 0.810. CFP in 2011 and social responsibility performance in 2012 are positively related as the value of sig is 0.000 
when the significance level is 0.01 . When the confidence is above $99 \%$, current CFP and later period social responsibility performance are positively related. It is indicated that current financial performance in financial and insurance industry and later period social responsibility performance have a certain correlation.

Regression analysis. According to the results of regression analysis in Table 4, Table 5 and Table 6 , it can be seen that the coefficient $\mathrm{R}$ is 0.810 , the degree of fitting is good, and it's improved compared with previous regression analysis; the parts of explained variables that can be explained by model are more and vice versa. Moreover, the statistical observation $F$ is 13.113, and the corresponding sig value is 0.000 when the Significance level is 0.01 . So the overall linear relation between explained variables and explanatory variable is obvious; the linear model can be established.

According to the coefficient analysis on multiple regressions, the off-standard coefficient of CFP is 2.129, and the corresponding sig value is 0.000 when the Significance level is 0.01 , which means the CFP and social responsibility performance is positively related. It is indicated that the correlation between the two performances is obvious although the two regression analyses are made; according to the degree of fitting, current CFP and later period social responsibility performance fitting is higher, which indicates current financial performance and later period social responsibility performance are positively related.

Table 4 Model Summary ${ }^{\mathrm{b}}$

\begin{tabular}{|c|c|c|c|c|}
\hline Model & R & R Square & $\begin{array}{c}\text { Adjusted R } \\
\text { Square }\end{array}$ & $\begin{array}{c}\text { Std. Error of } \\
\text { the Estimate }\end{array}$ \\
\hline 1 & $0.810^{\mathrm{a}}$ & 0.656 & 0.642 & 10.06132 \\
\hline
\end{tabular}

a. Predictive variable (constant), financial performance.

b. Dependent variable: social responsibility performance.

Table 5 ANOVAb

\begin{tabular}{|c|c|c|c|c|c|}
\hline Model & Sum of square & df & Mean Square & F & sig \\
\hline $\begin{array}{c}\text { Regression } \\
\text { Residual } \\
\text { Total }\end{array}$ & 4829.289 & 1 & 4829.289 & $\begin{array}{c}13.11 \\
3\end{array}$ & $0.000^{\mathrm{a}}$ \\
\cline { 2 - 6 } & 2530.752 & 25 & 101.230 & & \\
\cline { 2 - 6 } & 7360.041 & 26 & & & \\
\hline
\end{tabular}

a. Predictive variable (constant), financial performance.

b. Dependent variable: social responsibility performance.

Table 6 Coefficientsa

\begin{tabular}{|c|c|c|c|c|c|}
\hline Model & \multicolumn{2}{|c|}{$\begin{array}{c}\text { Unstandardized } \\
\text { Coefficients }\end{array}$} & $\begin{array}{c}\text { Standardized } \\
\text { Coefficients }\end{array}$ & \multirow{2}{*}{$\mathrm{T}$} & sig \\
\hline 1 & B & Std. Error & Beta & & \\
\hline \multirow{2}{*}{$\begin{array}{c}\text { (constant) } \\
\text { CFP }\end{array}$} & 27.787 & 4.618 & & 6.017 & 0.000 \\
\cline { 2 - 5 } & 2.129 & 0.308 & 0.810 & 3.549 & 0.001 \\
\hline
\end{tabular}

a. Dependent variable: social responsibility performance

Correlation between current enterprise social responsibility performance and current financial performance. Correlation analysis: The paper made correlation analysis by selecting related data of social responsibility performance in 2010 and financial performance in 2011 and 
received the result which was 0.796 . Social responsibility performance and financial performance are positively related, which indicates previous enterprise social responsibility performance and current financial performance have certain correlation and it's obvious.

Regression analysis. According to the results of regression analysis in Table 7, Table 8 and Table 9, it can be seen that the coefficient $\mathrm{R}$ is 0.796 , the degree of fitting is good; although the value goes down, the parts of explained variables that can be explained by model are more and vice versa. Moreover, the statistical observation $\mathrm{F}$ is 43.199 , sig value is 0.000 , so the overall linear relation between explained variables and explanatory variable is obvious; the linear model can be established.

According to the coefficient analysis on multiple regressions, the off-standard coefficient of CFP is 0.280 ; and the corresponding sig value is 0.000 when the significance level is 0.01 , which means the CFP and social responsibility performance are relevant. It can be seen from the comparison between previous and later period that the higher degree of fitting of the regression equation established between financial performance and social responsibility performance indicates the obvious positive correlation between each other.

Table 7 Model collection $^{\mathrm{b}}$

\begin{tabular}{|l|c|c|c|c|}
\hline Model & $\mathrm{R}$ & R Square & $\begin{array}{c}\text { Adjusted R } \\
\text { Square }\end{array}$ & $\begin{array}{c}\text { Std. Error of } \\
\text { the Estimate }\end{array}$ \\
\hline 1 & $0.796^{\mathrm{a}}$ & 0.633 & 0.280 & 3.95228 \\
\hline
\end{tabular}

a. Predictive variable (constant), social responsibility performance.

b. Dependent variable: financial performance.

Table 8 Anovab

\begin{tabular}{|l|c|c|c|c|c|}
\hline Model & Sum of square & df & Mean Square & F & sig \\
\hline \multirow{2}{*}{$\begin{array}{c}\text { Regression } \\
\text { Residual } \\
\text { Total }\end{array}$} & 674.786 & 1 & 674.786 & 43.199 & $0.000^{\mathrm{a}}$ \\
\cline { 2 - 7 } & 390.512 & 25 & 15.620 & & \\
\cline { 2 - 7 } & 1065.298 & 26 & & & \\
\hline
\end{tabular}

a. Predictive variable (constant), social responsibility performance.

b. Dependent variable: financial performance.

Table 9 Coefficientsa

\begin{tabular}{|c|c|c|c|c|c|}
\hline \multirow{2}{*}{ Model } & \multicolumn{2}{|c|}{$\begin{array}{c}\text { Unstandardized } \\
\text { Coefficients }\end{array}$} & $\begin{array}{c}\text { Standardized } \\
\text { Coefficients }\end{array}$ & \multirow{2}{*}{$\mathrm{T}$} & sig \\
\hline 1 & $\mathrm{~B}$ & Std. Error & Beta & & \\
\hline \multirow{2}{*}{$\begin{array}{c}\text { (constant) } \\
\text { CFP }\end{array}$} & 1.490 & 2.419 & & 0.616 & 0.543 \\
\cline { 2 - 5 } & 0.280 & 0.043 & 0.796 & 6.573 & 0.000 \\
\hline
\end{tabular}

a. Dependent variable: financial performance.

\section{Conclusion}

Current enterprise financial performance and current social responsibility performance are positively related. It is indicated that the premise for enterprise fulfilling social responsibility is to have enough capital input. With good financial performance, enterprises can actively fulfill social 
responsibilities and improve social responsibility performance. Therefore, financial performance affects social responsibility performance to some extent.

Current enterprise financial performance and later period social responsibility performance are positively related. Due to the time-lag of social responsibility performance, the degree of fitting of regression equation established by current enterprise financial performance and later period social responsibility performance is relatively higher, which means better current financial performance creates better later period social responsibility performance and urges enterprise to perform social responsibility better.

Previous enterprise social responsibility performance and current financial performance are positively related. The degree of fitting of regression equation established by previous enterprise social responsibility performance and current financial performance is higher, which means better previous social responsibility performance creates better current financial performance; enterprise actively improves social responsibility performance, and the financial performance will be improved as well.

\section{References}

[1]Oriental wealth website. http://www.eastmoney.com/

[2]Rankins CSR Ratings. http://www.rksratings.com/

[3]Lansang, W. Carroll. Correlation between the glucose clamp technique and the homeostasis model assessment in hypertension.Am J Hypertens, 14.1 (2001) 51-53.

[4]Van Beurden, Pieter, and Tobias Gössling.The worth of values-a literature review on the relation between corporate social and financial performance.Journal of business ethics 82.2 (2008)407-424.

[5] Wang Xiaoying, Lin Li. Discussion on accounting information disclosure of social responsibility from listed financial enterprises in China [J]. Oriental research, 2014, (1):152-161.

[6] Kong Long, Zhang Xianhua. Empirical analysis on correlation between enterprise social responsibility performance and enterprise economic performance $[\mathrm{J}]$. Journal of Ocean University of China, 2012,(4):80-84.

[7]Yang Hongxin. Correlation research on enterprise social responsibility and financial performance based on multiple regression model [J]. Friends of Accounting, 2014, (5):105-108.

[8] Li Yuanhui, Chen Jie. Correlation research on enterprise social responsibility performance and financial performance[J]. Statistics and decision, 2014, (11):176-178.

[9]Xue Wei. Statistical analysis and SPSS application[M]. Beijing: China Renmin University Press, 2011, (1):236-279. 